\title{
Quality and antioxidant potential of byproducts from refining of fruit pulp
}

\author{
Andréia AMARIZ1 ${ }^{1}$ Maria Auxiliadora Coêlho de LIMA ${ }^{2 *}$, Ricardo Elesbão ALVES ${ }^{3}$
}

\begin{abstract}
The potential use of byproducts from fruit processing has been evaluated in order to propose new uses as well as reducing costs and environmental impact. Most of the studies are focused on byproducts from primary transformation. However, byproducts from secondary transformation can reserve similar reuse opportunities. The aim of this study was to characterize chemical composition and antioxidant capacity that remained on byproducts from fruit processing at the pulp refinement stage. The byproducts from pulp refining were evaluated in cashew, cocoa, cupuassu, genipap, papaya, passion fruit seed, plum, soursop (pulp and seeds), strawberry, tamarind (pulp and seeds), umbu and yellow mombin fruits. Water activity, acidity, $\mathrm{pH}$, soluble solids, sugars, starch, pectins, ascorbic acid, carotenoids and polyphenols, and the antioxidant activity were analyzed. The byproducts from the refinement of soursop related to the fibrous pulp showed the highest soluble solids and pectic compounds content, while the seeds byproducts constituted a source of starch. The byproducts from the refining of pulp from yellow mombin and papaya were sources of carotenoids. The highest starch and polyphenols contents, as well as antioxidant activities peak on the refining of byproducts of tamarind. The byproducts studied maintained chemical compounds and bioactive components that hold potential reuse.
\end{abstract}

Keywords: ABTS; carbohydrates sources; carotenoids; chemical composition; polyphenols.

Practical Application: The potential use of byproducts from fruit processing industries.

\section{Introduction}

The active principles contained in fruits, namely organic acids, vitamins, mucilage, polyphenolic pigments, flavonoids, minerals, proteins and amino acids, are important components in dealing with aging effects, and on prevention of chronically degenerative diseases (Ordoñez-Santos et al., 2014). Epidemiological studies have shown the correlation between the consumption of foods derived from plants and plural health benefits. Several plants have been studied as natural antioxidant sources that are potentially safe for the food industry, and some compounds have been isolated (Figueiredo, 2010; Finetto, 2009).

Due to these beneficial features, which are present in foods of plant origin, there is a growth in interest in products derived from fruit because of the consumer's profile, who sees a correlation between quality and daily health protection obtained by its direct consumption or, through products containing parts, extracts or components of fruits (Finetto, 2009). These products development are available for companies on the primary or secondary sectors. The secondary transformation consists in manufacturing finished products with semi-processed raw material. Some examples of products from this segment are candied fruits, jellies, fruit pastes, juices, pulps, nectars and still drinks (Cunha et al., 2008).
In order to evaluate the potential health protection afforded by fresh fruits and their products, as already documented in the literature (Omena et al., 2012; Paz et al., 2015; Rufino et al., 2010; Valente et al., 2011), other studies should point out the maximum utilization of products and materials generated by the agroindustrial activity. This perspective has arisen an interest in the use of byproducts, which also brings an opportunity to prospect chemical compounds for new uses (Damiani et al., 2012; Figueiredo, 2010; Ordoñez-Santos et al., 2014; Pereira et al., 2013; Saratale et al., 2017; Silva et al., 2012; Sousa et al., 2011).

Fruit processing render high amounts of byproducts, which lead to losses of biomass, nutrients and energy, and as a secondary side effect they enhances environmental problems due to the great volume of residues inadequately stored, leading to soil and water pollution from the leaching organic compounds, resulting also in public health problems. To solve these issues, huge investments are required for their treatment, transportation and disposal, which influence the price of the final product (Damiani et al, 2012; Ordoñez-Santos et al, 2014; Sousa et al., 2011).

The problem of agri-food industrial byproducts and waste generation has attracted scientific, economic, political and commercial interest and urged the European Union towards a zero-waste economy by 2025 . To this direction, some scientific 
findings provide opportunities for reuse of food outputs leading to the development of innovative products (Naziri et al., 2014). However, most of those scientific findings focused on the primary transformation.

The secondary sector transformations do not produce vast amounts of byproducts rather acquire them at different stages, such as pulp, in the refinement, which contains unique characteristics while still keeping bioactive molecules in its composition (Finetto, 2009). The author mentions the case of the passion fruit, where cosmetic companies acquire seeds, which are byproducts, generated from the refining of the pulp of juices in large processing industries, given the quantity and quality of essential oils that are extracted and used to make their products.

Information about quality, bioactive compounds content and antioxidant activity of byproducts are essential to guide ways for their reuse and map industrial sectors interested in their usage as food additives (Damiani et al., 2012), or further as substrate for extracting of relevant compounds, such as antioxidants (Naziri et al., 2014; Pereira et al., 2013), for pharmaceutical and cosmetic purposes.

Sousa et al. (2011) characterized, nutrition wise, byproducts from fruit processing for frozen pulp, originated from an agroindustry, and have concluded that acerola and guava byproducts are potential sources of carotenoids, polyphenols and vitamin $\mathrm{C}$, which highlights their potential reuse. However, the influence of growing conditions on fruit quality, the type of processing and stage at which byproducts are generated, account for specific research and actions for different realities. These actions would be supportive of a clear identification of the opportunities of reprocessing when taking into consideration the differentiated characteristics of materials originated from different regions.

Byproducts originated from different raw materials and stages of fruit processing require knowledge in order to be transformed into value-added materials. It is necessary to know the components that attribute them quality, such as carbohydrates, pectins, pigments and others. Therefore, the aim of this study was to characterize chemical composition and antioxidant capacity retained within byproducts of fruit processing generated at the pulp refinement stage.

\section{Materials and methods}

The byproducts from the fruit processing stage, called refining or pulping were obtained from a company located in Juazeiro, State of Bahia. The fruit processing pulp industry that supplied the byproducts, purchases the raw materials from companies of the primary sector already pre-processed (cut and peeled) and frozen in barrels with an average capacity of $180 \mathrm{~L}$ and then processes them (Figure 1). The byproducts originated from the refining of pre-processed and frozen pulps of the following fruits: cashew (Anacardium occidentale L.), cocoa (Theobroma cacao L.), cupuassu (Theobroma grandiflorum Schum.), genipap (Genipa americana L.), papaya (Carica papaya L.), passion fruit (Passiflora edulis Sims. f. flavicarpa Degener), plum (Prunus salicina Lindl.), soursop (Annona muricata L.), strawberry (Fragaria $\mathrm{x}$ ananassa Duch.), tamarind

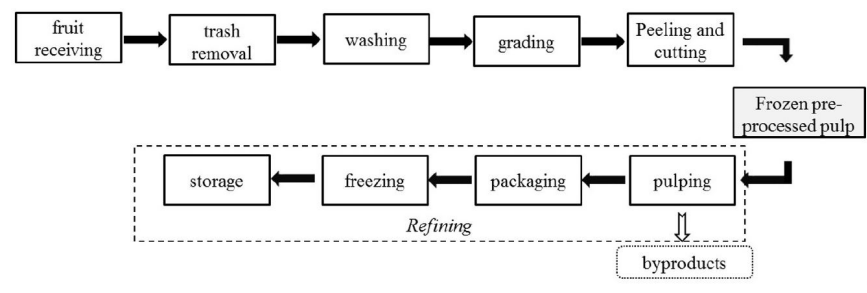

Figure 1. General flow process diagram for fruit pulp processing showing the stage where byproducts were collected for characterizing.

(Tamarindus indica L.), umbu (Spondias tuberosa Arr. Câm.) and yellow mombin (Spondias mombin L.) fruits. Most of the byproducts constituted of pulpy material, except for soursop, that had materials supplied separately, fibrous material of pulp and seeds; passion fruit, corresponding to seeds; and tamarind, which had pulp and seed supplied separately.

The collection of samples happened from the second semester of 2014 to the first semester of 2015. After each collection of byproducts samples, they were transported in thermal boxes to the Postharvest Physiology Laboratory of Embrapa Semiárido. They were stored in freezers for further evaluation.

The evaluation of the quality of the byproducts, originated from refinement, included the following variables: water activity $\left(\mathrm{A}_{\mathrm{w}}\right)$, measured with Aqualab device CX-2T model (Decagon Devices Inc., Pullman, WA); soluble solids (SS) content, determined in ${ }^{\circ}$ Brix directly from samples for most byproducts, with the exception of soursop and tamarind seeds, which used $1 \mathrm{~g}$ of the grounded sample diluted in $1 \mathrm{~mL}$ of distilled water for further reading, by the use of a digital refractometer with automatic temperature compensation (ATAGO, model PAL-1 Digital Pocket Refractometer, USA) (Association of Official Agricultural Chemists, 1992); titratable acidity (g prevailing acid. $100 \mathrm{~mL}^{-1}$ ): titration with $0.1 \mathrm{~N} \mathrm{NaOH}$ solution using phenolphthalein as an indicator (Instituto Adolfo Lutz, 2008); hydrogenionic potential - $\mathrm{pH}$ (Association of Official Agricultural Chemists, 1992), by immersion of the electrode into the sample for most byproducts, except for the soursop and tamarind seeds, which used $1 \mathrm{~g}$ of grounded sample diluted in $10 \mathrm{~mL}$ of distilled water for subsequent determination; total soluble sugars - TSS, with assay done with anthrone reagent (Yemn \& Willis, 1954), and reducing sugars - RS (Miller, 1959), quantified with the 3,5-dinitrosalicylic acid (DNS), both expressed in $\mathrm{g} .100 \mathrm{~g}^{-1}$; starch content, extraction with acid hydrolysis and assay with DNS, expressed in $\mathrm{g} .100 \mathrm{~g}^{-1}$ (Miller, 1959); and total pectic compounds (mg.100 $\mathrm{g}^{-1}$ ), according to the extraction described by McCready \& McComb (1952) and assay with galacturonic acid as standard (Blumenkrantz \& Asboe-Hansen, 1973).

The bioactive compounds analyzed were: ascorbic acid, expressed in mg.100 g ${ }^{-1}$ (Strohecker \& Henning, 1967); total carotenoids, quantified with petroleum ether and expressed in $\mu \mathrm{g} . \mathrm{g}^{-1}$ (Rodriguez-Amaya, 2001); and total extractable polyphenols (TEP), extracted with methyl alcohol (50\%) and acetone (70\%), corresponding to the first and second extractor solvents and results expressed in mg gallic acid. $100 \mathrm{~g}^{-1}$ (Larrauri et al., 1997). The total antioxidant activity was determined by the 
ABTS radical capture method, with the results expressed in $\mu \mathrm{M}$ Trolox.g pulp ${ }^{-1}$ (Miller et al., 1993, with the adaptations adopted by Rufino et al., 2010).

A completely randomized experimental design was adopted, with treatments corresponding to the byproducts from the pulp refinement. The byproducts were evaluated counting with four replicates, of approximately $2 \mathrm{~kg}$ of fresh material each. Results were expressed as the means \pm standard deviation.

\section{Results and discussion}

The byproducts that were analyzed presented values that had intrinsic characteristic for each one, for the majority of studied variables. The byproducts represented by soursop and tamarind seeds showed lower water activity (Aw) values of 0.52 and 0.59 (Table 1), which potentially enhances the preservation of compounds of interest and prevents losses due to degradative reactions or contamination by microorganisms.

The other byproducts obtained from pulp refining showed Aw higher than 0.89 , similar to what was observed by Diniz et al. (2003) in acerola concentrated pulp, which is within the expected range for high-moisture foods. These authors explain that Aw is a measure of water availability for the growth of microorganisms, whether deteriorating or not, and also for the occurrence of reactions such as browning, oxidation and hydrolysis, which may greatly influence food quality or provide information to processing, storage and even products fermentation.

Considering the variable soluble solids content (SSC), the byproduct from soursop seed generated in the pulp refining exhibited the lowest value $\left(1.8^{\circ} \mathrm{Brix}\right)$, and the highest values were found in byproducts of passion fruit seed, cocoa and

Table 1. Water Activity - Aw, soluble solids content - SSC ( ${ }^{\circ}$ Brix), titratable acidity - TA (g of prevailing acid. $100 \mathrm{~mL}^{-1}$ ) and $\mathrm{pH}$ of byproducts from pre-processed fruit pulp refining.

\begin{tabular}{lcccc}
\hline $\begin{array}{c}\text { pre-processed } \\
\text { fruit pulp }\end{array}$ & Aw & SSC & $\mathrm{TA}^{*}$ & $\mathrm{pH}$ \\
\hline cashew & $0.91 \pm 0.01$ & $5.5 \pm 0.8$ & $0.55 \pm 0.05$ & $4.01 \pm 0.11$ \\
cocoa & $0.95 \pm 0.01$ & $12.9 \pm 0.1$ & $0.78 \pm 0.01$ & $3.92 \pm 0.03$ \\
cupuassu & $0.92 \pm 0.01$ & $7.3 \pm 0.6$ & $2.13 \pm 0.03$ & $3.12 \pm 0.01$ \\
genipap & $0.91 \pm 0.01$ & $6.9 \pm 0.9$ & $1.0 \pm 0.1$ & $3.41 \pm 0.03$ \\
papaya & $0.94 \pm 0.00$ & $9.5 \pm 0.1$ & $0.19 \pm 0.01$ & $5.3 \pm 0.3$ \\
passion fruit - & $0.94 \pm 0.01$ & $12.3 \pm 0.2$ & $1.5 \pm 0.2$ & $3.6 \pm 0.2$ \\
seeds & & & & \\
plum & $0.92 \pm 0.01$ & $13.7 \pm 0.4$ & $0.32 \pm 0.03$ & $3.7 \pm 0.3$ \\
soursop & $0.94 \pm 0.00$ & $10 \pm 1$ & $0.65 \pm 0.04$ & $3.3 \pm 0.3$ \\
soursop - & $0.52 \pm 0.02$ & $1.8 \pm 0.1$ & $0.61 \pm 0.04$ & $3.9 \pm 0.9$ \\
seeds & & & & \\
strawberry & $0.95 \pm 0.01$ & $5.5 \pm 0.1$ & $0.96 \pm 0.08$ & $3.17 \pm 0.04$ \\
tamarind & $0.89 \pm 0.02$ & $9.8 \pm 0.5$ & $10 \pm 1$ & $2.5 \pm 0.3$ \\
tamarind - & $0.59 \pm 0.01$ & $9.9 \pm 0.2$ & $0.6 \pm 0.1$ & $4.5 \pm 0.2$ \\
seed & & & & \\
umbu & $0.94 \pm 0.01$ & $5.5 \pm 0.3$ & $1.32 \pm 0.08$ & $2.7 \pm 0.1$ \\
yellow & $0.90 \pm 0.03$ & $6.5 \pm 0.7$ & $1.68 \pm 0.08$ & $2.90 \pm 0.07$ \\
mombin & & & & \\
\hline
\end{tabular}

${ }^{*}$ Expressed in g malic acid. $100 \mathrm{~mL}^{-1}$, for plum and soursop; g citric acid. $100 \mathrm{~mL}^{-1}$ for cashew, cocoa, cupuacu, genipap, papaya, passionfruit, strawberry, tamarind, umbu and yellow mombin. plum, with the respective averages of $12.3,12.9$ and $13.7^{\circ} \mathrm{Brix}$ (Table 1). Intermediate values (5.4-7.3 ${ }^{\circ} \mathrm{Brix}$ ) were found in the pulp refining byproducts of cashew, strawberry, umbu, yellow mombin, genipap and cupuassu. The byproducts from pulp refinement of papaya, soursop, tamarind and tamarind seed showed SSC around $9^{\circ}$ Brix. In this study, the byproducts characterized by intermediate and high SSC values be suggested as a natural additive to improve flavor in industrial foods.

Higher values of SSC were found by Alcântara et al. (2012) in cashew peduncle byproducts and passion fruit peel, with values of 30-36.7 ${ }^{\circ}$ Brix, but they were measured on dry weight basis. These high concentrations of sugars could be useful to support fermentative processes as they supply the carbohydrates needs for the growth of microorganisms. Different SS values may be required either for human consumption or even for use as food additives.

The byproduct of the tamarind pulp refinement showed $10.11 \mathrm{~g}$ of citric acid.100 $\mathrm{mL}^{-1}$, standing out from the others (Table 1). The byproducts from genipap, umbu, passion fruit seed, yellow mombin and cupuassu pulp refining had an average of titratable acidity from 1.04 to $2.13 \mathrm{~g}$ of citric acid. $100 \mathrm{~mL}^{-1}$, while the others had values below $1 \mathrm{~g}$ of prevailing acid. $100 \mathrm{~mL}^{-1}$. Pereira et al. (2013) identified a titratable acidity of $4.68 \mathrm{~g}$ of malic acid. $100 \mathrm{~mL}^{-1}$ for acerola byproduct flour and suggested that high acidity is a good indicator of conservation, since acidic products are less prone to the growth of microorganisms.

Citric acid is widely used by the food industry, pharmaceutical products, among others, as it forms complex molecules that capture and inactivate metabolic ions. One of the major issues faced in its production is the high cost of the substrate. As an alternative, industrial byproducts with a proper acidity have been used as a culture medium in fermentations performed by microorganisms, as suggested by Silva et al. (2012). Similarly, byproducts from pulp refining of tamarind might be suggested for that same use.

From the values of $\mathrm{pH}$, the byproducts may be divided into two groups: the first corresponding to a low acid, above 4.5, which includes byproducts corresponding to papaya pulp and tamarind seed; and the second group of acids, which includes the others (Table 1). Higher acidity and $\mathrm{pH}$ were observed by Ordoñez-Santos et al. (2014) for the papaya processing byproducts: $0.27 \mathrm{~g}$ of citric acid. $100 \mathrm{~mL}^{-1}$ and 5.22 , respectively. Differences in the raw material, processing, water content of byproducts or others factors can explain the variation on values.

Soursop marketed in Sergipe State, Brazil, was evaluated by Marcellini et al. (2003) for physicochemical characteristics, it was recorded values for SSC of $12.2^{\circ}$ Brix, acidity of $0.57 \mathrm{~g}$ of citric acid. $100 \mathrm{~mL}^{-1}$ and $4.36 \mathrm{pH}$. The values observed in the present study for the byproduct from the pre-processed soursop pulp refinement were lower; this may be attributed to a less advanced maturity stage of the processed raw material, to specific growing conditions, and to the means of processing used. For example, the fruit pressing for pulp extracts soluble compounds, such as sugars and organic acids, which results in byproducts with reduced levels of these components. 
The byproducts that presented higher total soluble sugars (TSS) were generated from the refining of cocoa pulp, followed by soursop, papaya and plum (Table 2). The TSS content in relation to SSC displayed contents above $60 \%$ in the byproducts of cocoa, yellow mombin, cashew, soursop, genipap, papaya pulp refining and to the soursop seed.

For reducing sugars (RS) content, the byproducts of soursop and papaya pulp refinement had the highest values:

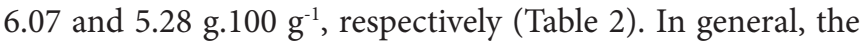
RS content of the byproducts followed the same trend, when rendering high proportion of TSS content, except for the cocoa, in which RS represented only $39 \%$ of the TSS.

Flours obtained from byproducts of the cashew peduncle and passion fruit albedo were characterized by Alcântara et al. (2012) for RS content, showing values of 31.12 and $17.73 \mathrm{~g} .100 \mathrm{~g}^{-1}$ on a dry basis, respectively. According to the authors, those values justify their use as a carbon source in semisolid fermentative processes for obtaining products.

Silva et al. (2012) while characterizing the byproduct of soursop for citric acid extraction and observed that the RS content, on a dry basis, were close to those obtained in this work in fresh matter basis. For the contents observed, the authors indicated the complementary use of glucose and yeast extract as sources of carbon and nitrogen in the fermentation process for the extraction of citric acid. The same can be suggested for soursop and papaya byproducts according to the results of this study.

There are opportunities of using other byproducts due to their composition as mentioned by some authors. For example, the use of apple dried bagasse for manufacturing bakery products resulted in foods rich in soluble sugars, pectins and fibers, but their contents present in this byproduct are influenced by the

Table 2. Total soluble sugars - TSS (g.100 $\left.\mathrm{g}^{-1}\right)$, reducing sugars - RS $\left(\mathrm{g} .100 \mathrm{~g} \mathrm{~g}^{-1}\right)$, total pectic compounds - Pectin $\left(\mathrm{mg} .100 \mathrm{~g}^{-1}\right)$ and starch $\left(\mathrm{g} .100 \mathrm{~g}^{-1}\right)$ contents of byproducts from pre-processed fruit pulp refinement.

\begin{tabular}{lcccc}
\hline $\begin{array}{l}\text { pre-processed } \\
\text { fruit }\end{array}$ & TSS & RS & Pectin & Starch \\
\hline cashew & $4.5 \pm 0.7$ & $4 \pm 1$ & $0.31 \pm 0.08$ & $1.01 \pm 0.07$ \\
cocoa & $9.5 \pm 0.2$ & $3.7 \pm 0.1$ & $0.55 \pm 0.02$ & $0.22 \pm 0.03$ \\
cupuassu & $3.6 \pm 0.1$ & $3.4 \pm 0.3$ & $0.25 \pm 0.06$ & $0.43 \pm 0.07$ \\
genipap & $5.1 \pm 0.8$ & $4.8 \pm 0.2$ & $0.82 \pm 0.05$ & $1.6 \pm 0.2$ \\
papaya & $6.28 \pm 0.09$ & $5.3 \pm 0.1$ & $0.9 \pm 0.2$ & $0.20 \pm 0.03$ \\
passion fruit - & $3.51 \pm 0.08$ & $3.2 \pm 0.2$ & $0.31 \pm 0.06$ & $1.4 \pm 0.2$ \\
seeds & & & & \\
plum & $6.74 \pm 0.07$ & $4.7 \pm 0.3$ & $1.7 \pm 0.1$ & $2.5 \pm 0.28$ \\
soursop & $6.11 \pm 0.08$ & $6.1 \pm 0.5$ & $1.4 \pm 0.1$ & $1.04 \pm 0.2$ \\
soursop - & $1.15 \pm 0.06$ & $1.0 \pm 0.1$ & $0.23 \pm 0.04$ & $12.5 \pm 0.5$ \\
seeds & & & & \\
strawberry & $3.1 \pm 0.1$ & $2.7 \pm 0.1$ & $0.58 \pm 0.07$ & $0.63 \pm 0.05$ \\
tamarind & $5.2 \pm 0.8$ & $4.6 \pm 0.3$ & $0.57 \pm 0.08$ & $1.32 \pm 0.04$ \\
tamarind - & $5.5 \pm 0.1$ & $4.8 \pm 0.2$ & $0.76 \pm 0.04$ & $31 \pm 2$ \\
seed & & & & \\
umbu & $2.55 \pm 0.06$ & $2.24 \pm 0.09$ & $1.0 \pm 0.1$ & $1.5 \pm 0.5$ \\
yellow & $4.8 \pm 0.5$ & $4.2 \pm 0.2$ & $0.30 \pm 0.08$ & $1.0 \pm 0.1$ \\
mombin & & & & \\
\hline
\end{tabular}

process in which they are obtained (type of milling and extraction process of soluble solids) and the processing, such as time and temperature (Coelho \& Wosiacki, 2010). Therefore, the byproducts that presented the highest TSS content, even after the second transformation, can be used for manufacturing food products.

From all the products which were evaluated, only the ones generated in the refining of plum and soursop pulps kept the highest pectic compounds content (Table 2). According to Alcântara et al. (2012), flours of the byproducts processing of cashew apple and passion fruit peel have both the potential to be used as a substrate for the production of enzymes used in food processing (pectinases) as for ethanol production (cellulases), since both show 10.67 and $16.66 \%$ calcium pectate on dry matter $(\mathrm{dm})$, respectively. The quantification of pectic compounds on dry basis is essential to show the potential of a byproduct to extract a component. The authors point out that food sources are rich in pectins, when values exceed $15 \%(\mathrm{dm})$.

In this study, the byproducts were originated from a second processing; therefore, it is possible that higher values of pectic compounds could have been observed in byproducts from the first processing.

The seed byproducts from the refining of tamarind and soursop pulps differed by higher starch content: 31.10 and $12.50 \mathrm{~g} .100 \mathrm{~g}^{-1}$, respectively (Table 2 ). The lower contents were observed in the byproducts of pulp refining from cocoa, cupuassu, papaya and strawberry.

The employment of starch by the food industry provides opportunities for using different sources. Silva et al. (2013) characterized the starch of 'Tommy Atkins' mango kernel and studied its incorporation into a milk drink, and identified the concentration of $0.3 \%$ as satisfactory, enabling its action as a thickener which provided nice sensory and physicochemical attributes, qualifying it to be used in the food industry. It is suggested that the starch contents in byproducts from tamarind and soursop pulps are sufficient for its insertion in food products by offering a proper texture, increase in carbohydrates levels or other industrial aspects of interest.

Among the bioactive compounds, ascorbic acid is an excellent antioxidant, by capturing free radicals and preventing oxidative stress (Valente et al., 2011) through a daily intake of $60 \mathrm{mg} .100 \mathrm{~g} \mathrm{~g}^{-1}$, as mentioned by Pereira et al. (2013). This study showed that byproducts of pulp refinement from the pulp of yellow mombin, cashew, cupuacu, strawberry, tamarind and umbu retained values above the recommendation (Table 3 ).

The pulpy byproduct of cashew stood out among the others, especially in regards to the high content of ascorbic acid, which was considerably higher than the ones described by Sousa et al. (2011) in byproducts of acerola and guava, which are raw materials widely known as sources of this bioactive compound. The contents of ascorbic acid that have been observed in the byproducts mentioned can be isolated, considering the protective action of ascorbic acid in animal and plant tissues, to offer an antioxidant protection during or after processing to obtain products for different uses, such as food, pharmacological, therapeutic and cosmetic. 
Table 3. Ascorbic acid - AA (mg. $\left.100 \mathrm{~g}^{-1}\right)$, total carotenoids - TC $\left(\mu \mathrm{g} \cdot \mathrm{g}^{-1}\right)$, total extractable polyphenols - TEP (mg gallic acid.100 g $\left.\mathrm{g}^{-1}\right)$ content and antioxidant activity - ABTS ( $\mu \mathrm{M}$ Trolox. $\mathrm{g}^{-1}$ pulp) of byproducts of pre-processed fruit pulp refinement.

\begin{tabular}{|c|c|c|c|c|}
\hline pre-processed fruit pulp & AA & TC & TEP & ABTS \\
\hline Cashew & $232.60 \pm 12.37$ & $9.3 \pm 0.4$ & $753 \pm 207$ & $77 \pm 4$ \\
\hline Cocoa & $39.16 \pm 0.01$ & n.d. & $105 \pm 3$ & $7.7 \pm 0.7$ \\
\hline cupuassu & $64 \pm 10$ & $6.2 \pm 0.7$ & $118 \pm 4$ & $19 \pm 1$ \\
\hline genipap & $31 \pm 8$ & n.d. & $84 \pm 2$ & $5.47 \pm 0.04$ \\
\hline Papaya & $39.17 \pm 0.01$ & $50 \pm 1$ & $84 \pm 8$ & $99 \pm 7$ \\
\hline passion fruit - seeds & $56 \pm 5$ & $11 \pm 1$ & $297 \pm 14$ & $17 \pm 2$ \\
\hline soursop - seeds & $39.18 \pm 0.03$ & n.d. & $37 \pm 1$ & $63 \pm 3$ \\
\hline strawberry & $64 \pm 10$ & $13 \pm 1$ & $815 \pm 23$ & $174 \pm 18$ \\
\hline tamarind & $76 \pm 17$ & $2.8 \pm 0.1$ & $1011 \pm 86$ & $264 \pm 10$ \\
\hline tamarind - seed & $39.19 \pm 0.02$ & n.d. & $5920 \pm 98$ & $7783 \pm 78$ \\
\hline umbu & $69 \pm 20$ & $7.4 \pm 0.5$ & $24 \pm 2$ & $8.8 \pm 0.9$ \\
\hline
\end{tabular}

n.d.= non determined, since these compounds were not present in the pulp of fruit.

Pereira et al. (2013), studying an acerola byproduct flour detected an ascorbic acid content of $31.03 \mathrm{mg} .100 \mathrm{~g}^{-1}$, therefore it could be considered as a complementary source for this nutrient. In addition, they also reported the influence of the maturity stage of the raw material, and especially of the processing, on the ascorbic acid content.

Carotenoids have received considerable attention as a bioactive compound due to its distinctive physiological functions, such as pro-vitamins and antioxidant effects, especially in capturing the singlet oxygen (Ordoñez-Santos et al., 2014; Sousa et al., 2011).

Byproducts from pulp refining of yellow mombin and papaya showed the highest total carotenoids content: 70.60 and $49.76 \mu \mathrm{g} \cdot \mathrm{g}^{-1}$, respectively (Table 3 ). Both are classified as having very high levels of these pigments and even the byproducts, which are in the range of 5-20 $\mu \mathrm{g} \cdot \mathrm{g}^{-1}$ in carotenoids content. Those values confirm the potential of reprocessing byproducts from the pulp refining of fruits aforementioned to increase the provitamin A activity, mainly in food products deprived of these pigments. For example, it is possible to enrich products of restricted nutritional value, such as extrudates, with these compounds or simply use it as a natural pigment.

Sousa et al. (2011), also evaluated the total carotenoids content in cupuassu and soursop by-products from the refining, and they determined values of 1.27 and $0.21 \mu \mathrm{g} . \mathrm{g}^{-1}$, respectively. In byproducts from papaya processing, it was reported a content of $58.8 \mu \mathrm{g} \cdot \mathrm{g}^{-1}$ by Ordoñez-Santos et al. (2014).

Paz et al. (2015) disclose that many food products need to be protected by the addition of preservatives, and the trend to avoid chemical compounds in foods is leading to the exploration and development of alternative natural substances that are able to increase the shelf life of foods. Some may also provide some safety, regarding foodborne pathogens, with a reduced potential of promoting hypersensitivity reactions.

Another important group of chemical compounds for the human diet are polyphenols. The following pulp refining byproducts displayed high polyphenol content: yellow mombin, cashew, strawberry, tamarind pulp and its seed, with values above $500 \mathrm{mg}$ EAG.100 $\mathrm{g}^{-1}$ (Table 3). The polyphenol content in the byproducts from tamarind pulp and seed showed the highest values. In a previous study carried out by Luzia \& Jorge (2011) it is reported a high polyphenol content in fresh tamarind seed extract, registered as $4930 \mathrm{mg}$ EAG. $100 \mathrm{~g}^{-1}$. The present study distinguish the potential of these byproducts as sources of phenolic compounds.

The byproducts of the refining of plum and strawberry presented a total extractable polyphenol content of 80.72 and 814.76 mg EAG.100 g ${ }^{-1}$ (Table 3). Machado et al. (2013) studied the effect of processing and storage (rise in temperature, $\mathrm{pH}$ changes and cycle freeze/thaw) on phenolic compounds content in aqueous extracts of black plum and freshly processed strawberry, and observed averages of 57.67 and $107.30 \mathrm{mg}$ EAG.100 g $\mathrm{g}^{-1}$. The authors have concluded that temperature changes, and the grinding of samples, account for the highest degradation rates for the total phenolic compounds.

The refined pulp of passion fruit presented a polyphenol contents of $70.6 \mathrm{mg}$ EAG.100 g-1 (Table 3). Rufino et al. (2010) reported a concentration for the total extractable polyphenol content from the fresh and intact passion fruit of $72 \mathrm{mg}$ EAG. $100 \mathrm{~g}^{-1}$, while Paz et al. (2015) observed that the lyophilization process have contributed to the maintenance of the polyphenol contents of $744 \mathrm{mg}$ EAG. $100 \mathrm{~g}^{-1}$.

Polyphenol content extracted with ethanol in genipap pulp and umbu peel were analyzed on a dry basis by Omena et al. (2012), and values of 6160 and $5250 \mathrm{mg}$ EAG. $100 \mathrm{~g}^{-1}$ were observed. Sousa et al. (2011) quantified the total phenolic content in byproducts from fresh tropical fruit and observed the value of $4.66 \mathrm{mg} .100 \mathrm{~g}^{-1}$ for the aqueous extract of cupuassu. This value, which is below the mean registered in this research, might be associated with the extractor solvent used during the analytical procedure, which may have been less efficient than the one utilized for the byproducts in this study. 
The bioavailability of polyphenols may be affected by factors of environmental nature, such as radiation, maturity stage and processing (heat treatments and homogenization), and internal factors, such as interaction with other compounds (proteins and even other polyphenols with similar uptake mechanism). It is essential to point out that the methods and the solvent used in the extraction can greatly influence the phenolic content in food, as the extraction efficiency is associated with the polarity (Machado et al., 2013).

The antioxidant activity, registered for byproducts from pulp refinement of yellow mombin, strawberry and tamarind, was elevated: ranging from 115.24 to $264.16 \mu \mathrm{M}$ Trolox.g ${ }^{-1}$ (Table 3 ). In correlation to the high TEP content, the byproduct of tamarind seeds showed the highest antioxidant capacity by the ABTS method $\left(7782.69 \mu \mathrm{M}\right.$ Trolox. $\left.\mathrm{g}^{-1}\right)$, indicating a relationship between those variables. As recommended by Omena et al. (2012), natural sources of antioxidant activity, such as byproducts from umbu peel and genipap pulp, can be used in the preparation of foods or in pharmaceutical and cosmetics industries for the development of different products to delay and/or prevent the action of free radicals. This study shows the potential application of byproducts from pulp refining of some fruit for the uses mentioned above. However, the complexity of biological systems does not always lead to predictable responses. Then, Paz et al. (2015) reinforce that synergistic or antagonistic effect between the different phenols present cannot be ruled out. In addition to the structure-function relation of natural antioxidants present in constituent fruits parts, factors such as food physical condition, storage conditions and water activity, affect also those compounds efficiency.

As suggested by Saratale et al. (2017), the recovered biomolecules from byproducts and that are related to biological properties, such as antimicrobials, antioxidants, flavorings, pigments and thickening agents, can be a wide field of exploitation for producing functional foods or additives in food products to extend their shelf-life besides medicinal and pharmaceutical preparations. And the chemical composition of byproducts from refining studied in this work revealed some of them as a promising source of compounds that can be used for their nutritional properties and biological potential. These compounds can be incorporated as functional and technical ingredients for new industrial products.

\section{Conclusions}

Although the byproducts studied were originated from secondary transformations, they held considerable amounts of chemical properties and bioactive components and held the potential use in food industry as well as in other uses. The uses vary according to the predominant chemical compound, which content allow other stage of industrialization. The byproducts from soursop fibrous pulp refinement constituted a natural source of soluble solids and pectic compounds, and those from the seeds represented a source of starch. Regarding the byproducts from pulp refining of yellow mombin and papaya they were indicated as sources of carotenoids and the byproducts from the refinement of cashews contained high ascorbic acid content. Lastly, the highest polyphenols content, as well as elevated antioxidant activities gathered around the byproducts from the refinement of tamarind seeds and fibrous pulp. Observing all characteristics, the byproducts from tamarind and of yellow mombin pulp were better in relation to their antioxidant properties.

\section{References}

Alcântara, S. R., Sousa, C. A. B., Almeida, F. A. C., \& Gomes, J. P. (2012). Caracterização físico-química das farinhas do pedúnculo do caju e da casca do maracujá. Revista Brasileira de Produtos Agroindustriais, 14, 473-478. http://dx.doi.org/10.15871/1517-8595/ rbpa.v14nEspecialp473-478.

Association of Official Agricultural Chemists - AOAC. (1992). Official methods of analysis of the Association of the Agricultural Chemists (11th ed.). Washington: AOAC.

Blumenkrantz, N., \& Asboe-Hansen, G. (1973). New method for quantitative determination of uronic acids. Analytical Biochemistry, 54(2), 484-489. http://dx.doi.org/10.1016/0003-2697(73)90377-1. PMid:4269305.

Coelho, L. M., \& Wosiacki, G. (2010). Avaliação sensorial de produtos panificados com adição de farinha de bagaço de maçã. Food Science and Technology, 30(3), 582-588. http://dx.doi.org/10.1590/S010120612010000300003.

Cunha, A. M., de Araújo, R. D., Mello, C. H., \& Boeira, J. L. F. (2008). Relatório de acompanhamento setorial: frutas processadas (Vol. 1). Campinas: UNICAMP. Retrieved from //www.funcex.org.br/ material/redemercosul_bibliografia/biblioteca/ESTUDOS_BRASIL/ BRA_151.pdf

Damiani, C., Silva, F. A., Rodovalho, E. C., Becker, F. S., Asquieri, E. R., Oliveira, R. A., \& Lage, M. E. (2012). Aproveitamento de resíduos vegetais para produção de farofa temperada. Alimentos e Nutrição, 22(4), 657-662.

Diniz, E., Figueirêdo, R. M. F., \& Queiroz, A. J. M. (2003). Atividade de água e condutividade elétrica de polpas de acerola concentradas. Revista Brasileira de Produtos Agroindustriais, 1, 9-17.

Figueiredo, P. (2010). Valorização de resíduos da indústria agroalimentar através do desenvolvimento de ingredientes funcionais e nutracêuticos. Studia, 13(2), 79-88.

Finetto, M. (2009). Frutas da beleza. Revista Frutas e Derivados, 4, 27-29. Retrieved from http://www.ibraf.org.br/x_files/revista13.pdf

Instituto Adolfo Lutz - IAL. (2008). Métodos físico-químicos para análise de alimentos (1020 p.). São Paulo: IAL.

Larrauri, J. A., Rupérez, P., \& Saura-Calixto, F. (1997). Effect of drying temperature on the stability of polyphenols and antioxidant activity of red grape pomace peels. Journal of Agricultural and Food Chemistry, 45(4), 1390-1393. http://dx.doi.org/10.1021/jf960282f.

Luzia, D. M. M., \& Jorge, N. (2011). Antioxidant activity, fatty acid profile and tocopherols of Tamarindus indica L. seeds. Food Science and Technology, 31(2), 497-501. http://dx.doi.org/10.1590/S010120612011000200034

Machado, W. M., Pereira, A. D., \& Marcon, M. V. (2013). Efeito do processamento e armazenamento em compostos fenólicos presentes em frutas e hortaliças. UEPG Ciências Exatas e da Terra. Ciências Agrárias e Engenharias, 19(1), 17-30.

Marcellini, P. S., Cordeiro, C. E., Faraoni, A. S., Batista, R. A., Ramos, A. L. D., \& Lima, A. S. (2003). Comparação físico-química e sensorial da atemoia com a pinha e a graviola produzidas e comercializadas no Estado de Sergipe. Alimentos e Nutrição, 14(2), 187-189. 
McCready, R. M., \& McComb, E. A. (1952). Extraction and determination of total pectic material in fruits. Analytical Chemistry, 24(12), 1586-1588.

Miller, G. L. (1959). Use of dinitrosalicylic acid reagent for determination of reducing sugars. Analytical Chemistry, 31(3), 426-428. http:// dx.doi.org/10.1021/ac60147a030.

Miller, N. J., Rice-Evans, C., Davies, M. J., Gopinathan, V., \& Milner, A. (1993). A novel method for measuring antioxidant capacity and its application to monitoring the antioxidant status in premature neonates. Clinical Science, 84(4), 407-412. http://dx.doi.org/10.1042/ cs0840407. PMid:8482045.

Naziri, E., Nenadis, N., Mantzouridou, F. T., \& Tsimidou, M. Z. (2014). Valorization of the major agrifood industrial by-products and waste from Central Macedonia (Greece) for the recovery of compounds for food applications. Food International Research, 65, 350-358. http://dx.doi.org/10.1016/j.foodres.2014.09.013.

Omena, C. M. B., Valentim, I. B., Guedes, G. S., Rabelo, L. A., Mano, C. M., Bechara, E. J. H., Sawaya, A. C. H. F., Trevisan, M. T. S., Costa, J. G., Ferreira, R. C. S., Sant’ana, A. E. G., \& Goulart, M. O. F. (2012). Antioxidant, anti-acetylcholinesterase and cytotoxic activities of etanol extracts of peel, pulp and seeds of exotic Brazilian fruits. Food Research International, 49(1), 334-344. http://dx.doi.org/10.1016/j. foodres.2012.07.010.

Ordoñez-Santos, L. E., Aguilar, P. H., Solarte, O. D. R., \& Jaramillo, M. E. A. (2014). Concentración de carotenoides totales em resíduos de frutas tropicales. Producción + Limpia, 9(1), 91-98.

Paz, M., Gúllon, P., Barroso, M. F., Carvalho, A. P., Domingues, V. F., Gomes, A. M., Becker, H., Longhinotti, E., \& Delerue-Matos, C. (2015). Brazilian fruit pulps as functional foods and additives: evaluation of bioactive compounds. Food Chemistry, 172, 462-468. http://dx.doi.org/10.1016/j.foodchem.2014.09.102. PMid:25442579.

Pereira, C. T. M., Silva, C. R. P., Lima, A., Pereira, D. M., Costa, C. N., \& Cavalcante, A. A. No. (2013). Obtenção, caracterização físico-química e avaliação da capacidade antioxidante in vitro da farinha de resíduo de acerola (Malpighia glabra L.). Acta Tecnológica, 8(2), 50-56.

Rodriguez-Amaya, D. B. (2001). A guide to carotenoids analysis in foods (71 p.). Washington: OMNI. Retrieved from http://beauty-review.
nl/wp-content/uploads/2014/11/A-guide-to-carotenoid-analysisin-foods.pdf

Rufino, M. S. M., Alves, R. E., Brito, E. S., Pérez-Jiménez, J., SauraCalixto, F., \& Mancini-Filho, J. (2010). Bioactive compounds and antioxidant capacities of 18 non-traditional tropical fruits from Brazil. Food Chemistry, 121, 996-1002. http://dx.doi.org/10.1016/j. foodchem.2010.01.037.

Saratale, R. G., Shin, H.-S., Kumar, G., Benelli, G., Ghodake, G. S., Jiang, Y. Y., Kim, D. S., \& Saratale, G. D. (2017). Exploiting fruit byproducts for eco-friendly nanosynthesis: Citrus $\times$ clementina peel extract mediated fabrication of silver nanoparticles with high efficacy against microbial pathogens and rat glial tumor C6 cells. Environmental Science and Pollution Research International. http:// dx.doi.org/10.1007/s11356-017-8724-z. PMid:28303540.

Silva, G. A. S., Cavalcanti, M. T., Almeida, M. C. B. M., Araújo, A. S., Chinelate, G. C. B., \& Florentino, E. R. (2013). Utilização do amido da amêndoa da manga 'Tommy Atkins' como espessante em bebida láctea. Revista Brasileira de Engenharia Agrícola e Ambiental, 17(12), 1326-1332. http://dx.doi.org/10.1590/S1415-43662013001200011.

Silva, G. K. C., Ramalho, S. A., Gualberto, N. C., Gomes, E. B., Miranda, R. C. M., \& Narain, N. (2012). Utilização de resíduo agroindustrial como matéria-prima para a produção de ácido cítrico por Kluveromyces marxianus URM 4404. Scientia Plena, 8(5), 1-6.

Sousa, M. S. B., Vieira, L. M., Silva, M., \& Lima, A. (2011). Caracterização nutricional e compostos antioxidantes em resíduos de polpas de frutas tropicais. Ciência e Agrotecnologia, 35(3), 554-559. http:// dx.doi.org/10.1590/S1413-70542011000300017.

Strohecker, R., \& Henning, H. M. (1967). Analisis de vitaminas: métodos comprobados. (428 p.). Madrid: Paz Montalvo.

Valente, A., Albuquerque, T. G., Sanches-Silva, A., \& Costa, H. S. (2011). Ascorbic acid content in exotic fruits: a contribuition to produce quality data for food composition databases. Food Research International, 44(7), 2237-2242. http://dx.doi.org/10.1016/j.foodres.2011.02.012.

Yemn, E. W., \& Willis, A. J. (1954). The estimation of carbohydrate in plant extracts by anthrone. The Biochemical Journal, 57, 504-514. 